\title{
Socio-Economic Implication of Nigeria Liquefied Natural Gas (NLNG) Project in Bonny Local Government Area, Rivers State, Nigeria
}

\author{
Oluyemi Ayorinde Akintoye1, Abiodun Komomo Eyong2, Peter Okpe Agada ${ }^{3}$, \\ Opaminola Nicholas Digha1, Okibe James Okibe1 \\ ${ }^{1}$ Department of Geography and Environmental Science, University of Calabar, Calabar, Nigeria \\ ${ }^{2}$ Department of Public Health, University of Calabar, Calabar, Nigeria \\ ${ }^{3}$ Department of Pharmacy, University of Calabar Teaching Hospital, Calabar, Nigeria \\ Email: oluyemi.akintoye@unical.edu.ng, komomoeyong@yahoo.com, pagada09@gmail.com, \\ dighsopsminola@yahoo.com, okibejames@gmail.com
}

Received 17 October 2015; accepted 9 May 2016; published 12 May 2016

Copyright (C) 2016 by authors and Scientific Research Publishing Inc.

This work is licensed under the Creative Commons Attribution International License (CC BY). http://creativecommons.org/licenses/by/4.0/

(c) (i) Open Access

\section{Abstract}

Notably, the Nigeria Liquefied Natural Gas (NLNG) project is the pioneer Liquefied Natural Gas (LNG) plant in Nigeria, aimed at both the diversification of the petroleum industry and utilization of the vastly flared natural gas resources of the nation. However, large scale energy projects have been known to generate both positive and/or negative impacts. Environmental Management Plans (EMP) have often been the compendium of information on approved mitigations, which normally include activities that could maximize the benefits of the host communities, and it's not unusual for the Community Development and Corporate Social Responsibility (CDCSR) department of such an organization to be saddled with these contributions. But the activities of Nigeria LNG Ltd.'s CSR department have often been the source of criticism, as well as aspiration for improvement by host communities and other stake holders. This article thus aims to present a comprehensive compendium of NLNG's CDCSR activities, up to the year 2010, and also highlight the level of satisfaction of the immediate and distant host communities against the level of performance of other donors in the area. Also the arrays of negative socio-economic consequences of the Nigeria LNG Ltd.'s activities were identified based on community perception. The results generally showed that comparatively, NLNG project has made more innovative positive socio-economic and health contributions to its areas of operation than the three tiers of government and other donors (including SPDC and Mobil Producing Nigeria). Surprisingly, agitations against Nigeria LNG Ltd.'s activities have not overshadowed its community development provisions, which have been of major assistance in several communities. There is however a dire need to review several aspects of Nigeria LNG Ltd.'s 
CDCSR activities, especially in the fulfilment of documented promises, as well as in project conception and community participation, for better completed projects acceptance by indigenous host communities. Conflict management strategies also need to be improved, while the dissatisfaction over benefits in New Finima needs to be urgently addressed.

\section{Keywords}

\section{Socio-Economic Development, Impact, Nigeria Liquefied Natural Gas (LNG) Limited, Niger Delta Area, Bonny Local Government Area}

\section{Introduction}

The economic and environmental implications of the long time uncontrolled gas flaring activities in Nigeria, are serious because the process results in a significant waste of very valuable fuel resources, which invariably, also pollute water, air, and soil on which human populations in the Niger Delta depend [1]. Nigeria still remains one of the most underdeveloped and corrupt countries in the world [2]. Foreign exchange earnings from crude oil sales, currently provides for nearly 80 percent of government revenue, over 90 percent of foreign exchange earnings, and 90 - 95 percent of export earnings.

Notably, more than 75 percent of this petroleum resource is found in the coastal areas of the Niger Delta, which is the largest oil reserve in Africa, as well as the tenth largest in the world [3]. According to the Ministry of Petroleum Resources, there are 150 oil fields and 1481 oil wells in the Niger Delta region [4]. These activities are characterized by large scale gas flaring which have continued for decades, and have been the source of major concern by environmentalists, due to its notable potentials for large scale environmental pollution, climate change and health implications in host communities.

If it is possible one would say, if these flared gases are used, then these problems of environmental pollution and other forms of degradation could arguably be solved. Thus, the need for a gas-using project, from which the host communities of natural gas utilizing projects, and invariably the country at large could equally benefit, arises. Observations by African News Service [5] on crude oil (and invariably gas resources) exploiting companies and the environment are also quite revealing, especially as regards the implications of gas flaring.

The Nigerian Liquefied Natural Gas (LNG) project is thus, strategically designed to utilize the abundant gas resources of the nation, which are paradoxically currently being wasted through decades of flaring, and associated with adverse consequences on the regional and invariably international climates. Thus the existing cleared plant site and residential area on Bonny Island were allocated to Nigeria LNG Ltd. (NLNG). The subsequent on-site activities involved the relocation of Old Finima by the Federal authorities and a purpose-built new town was provided. Relocation to New Finima town took place in 1991, after which the site was leveled and covered with hydraulic fill to raise the site to the correct levels for construction. The relocation of indigenous populations and confiscation of coastal areas, especially known to be breeding grounds for marine species, portends major ecological danger and cultural trauma to man and loss of vital habitat used for centuries by animal species.

All over the world, gas extracting and processing facilities are springing up. The number of LNG projects has even increased [6], faster than crude oil refineries, as crude oil reserves dwindle across the globe (Tables 1-3). The environmental, socio-economic and health implications are not presently adequately known as is the case of crude oil refineries worldwide. It's thus of great interest, to know the possible positive and/or negative socio-economic, health and ecological implications of a considerably a large project like the NLNG plant: to know if the impacts of LNG projects differ widely or slightly from those of the traditionally familiar, crude oil exploitation and processing facilities in rural areas? Or if there are strong similarities. However, of importance to this study is the understanding of the mitigation strategies adopted by LNG projects worldwide, and precisely, what have been the experiences in Corporate Social Responsibility (CSR) motivated community development activities by NLNG in Bonny Local Government Area?. What are the negative implications of the NLNG project? How has NLNG contributed to human health management in the study area.

The construction of the NLNG project includes road building for the project and community uses, as well as the laying of gas transmission pipelines, through relatively undisturbed areas, often open up such areas to secondary 
Table 1. Planned liquefaction terminals worldwide [6].

\begin{tabular}{|c|c|c|c|c|c|c|}
\hline \multicolumn{7}{|c|}{ Planned liquefaction terminals } \\
\hline Country & Location & Project developers & Status & $\begin{array}{l}\text { Planned } \\
\text { start up }\end{array}$ & $\begin{array}{l}\text { No. New } \\
\text { trains }\end{array}$ & $\begin{array}{c}\text { New } \\
\text { capacity } \\
\text { mtpa }\end{array}$ \\
\hline Abu Dhabi & Das Island (expansion) & Adgas & Studies & & 1 & \\
\hline Algeria & Skikda (rebuilding) & Sonatrach & Studies & 2007 & 1 & 3.8 \\
\hline Algeria & Arzew (Gassi Touil) & Sonatrach/Repso/Gas Natural & Studies & 2009 & 1 & 3.8 \\
\hline Angola & Soyo & $\begin{array}{l}\text { Sonangol, Chevron Texaco, } \\
\text { BP, ExxonMboil, Total }\end{array}$ & Studies & 2009 & 1 & 5 \\
\hline Australia & NWS Venture (Tr. 5) expansion) & $\begin{array}{l}\text { Woodside, Shell. BHP, BP, } \\
\text { Chevron Texaco, MIMI }\end{array}$ & $\begin{array}{l}\text { Impending } \\
\text { EPC }\end{array}$ & 2008 & 1 & 4.2 \\
\hline Australia & Barrow Island (Gorgon) & Chevron Texaco, Shell ExxonMobil & Studies & 2008 & 2 & 10 \\
\hline Australia & Tassie Shoal & Methanol Australia & Studies & 2010 & 1 & 2.5 \\
\hline Australia & Pilbra & BHP Petroleum & Studies & 2010 & & 6 \\
\hline Australia & Browse & Woodside & Studies & 2012 & & 10 \\
\hline Australia & Greater Sunrise & Woodside, Osaka Gas Phillips, Shell & Studies & 2009 & 1 & 5.3 \\
\hline Bolivia & Margarita (Pacific LNG) & Repsol, BG and BP & Dormant & & 2 & 7 \\
\hline Brazil & Solimoes (Green LNG) & Petrobras & Studies & 2008 & 1 & 2.5 \\
\hline Brunei & Lumut-Train 6 expansion & Brunei LNG & Studies & 2010 & 1 & 5 \\
\hline Egypt & $\begin{array}{l}\text { Idku-Train } 3 \text { expansion } \\
\text { Egyptian LNG) }\end{array}$ & $\begin{array}{c}\text { EGPC, EGAS, } \\
\text { Gas de France, Petronas }\end{array}$ & Studies & 2007 & 1 & 3.6 \\
\hline Egypt & Damietta-Train 2 expansion & ENI, EGPC, EGAS & FEED & 2007 & 1 & 5 \\
\hline Indonesia & Bontang-Tr.1 expansion & Pertamina, Total, Unocal VICO & FEED & 2007 & 1 & 3.5 \\
\hline Indonesia & Sulaawesi (Donggi LNG) & Pertamina, Medxo & Studies & 2007 & 2 & 7 \\
\hline Iran & Iran LNG & NICO, BP. Reliance & Studies & 2009 & 2 & 8 \\
\hline Iran & Pars LNG & NICO, Total Petronas & FEED & & 2 & 8 \\
\hline Iran & Persian LNG & NICO, Repsol, Shell & FEED & 2009 & 2 & 10 \\
\hline Iran & NIOC LNG & NICO, BG, Enel, Agip & Studies & 2009 & 2 & 9.6 \\
\hline Malaysia & Bintulu (exp.) & Malaysia LNG Petronas & Studies & & 1 & \\
\hline Mauritania & & BG & Studies & & & \\
\hline Nigeria & Bonny-Train 7 & NNPC, Shell, Total, ENI & Studies & & 1 & \\
\hline Nigeria & Bonny & NNPC/ExxonMobil & Studies & & 1 & 4.8 \\
\hline Nigeria & Brass LNG & $\begin{array}{l}\text { NNPC, Eni, ConocoPhillips, } \\
\text { Chevron Texaco }\end{array}$ & FEED & 2009 & 1 & 10 \\
\hline Nigeria & Nbwa Doro offshore FPSO & Statoil, Shell & Studies & 2009 & 4 & 5 \\
\hline Nigeria & Olokola & $\begin{array}{c}\text { NNPC, Chevron Nigeria, } \\
\text { BG and Shell }\end{array}$ & Studies & 2010 & 1 & 20 \\
\hline Nigeria & $\begin{array}{l}\text { West Niger Delta } \\
\text { (Western LNG) }\end{array}$ & $\begin{array}{l}\text { NNPC, ConocoPhillips, } \\
\text { Chevron Taxaco }\end{array}$ & Studies & 2008 & 1 & 5 \\
\hline Peru & $\begin{array}{l}\text { Pampa Melchoria } \\
\text { (Camisea LNG) }\end{array}$ & Hunt Oil < SK Corporation & FEED & 2008 & 1 & 4.5 \\
\hline Qatar & $\begin{array}{l}\text { Ras Laffan-expansion } \\
\text { (Qatargas III-Train 6) }\end{array}$ & $\begin{array}{c}\text { Qatar Petroleum (QGPC), } \\
\text { ConocoPhillips }\end{array}$ & FEED & 2009 & 1 & 7.5 \\
\hline Qatar & $\begin{array}{l}\text { Ras Laffan-expansion } \\
\text { Qatargas IV-Train 7) }\end{array}$ & QGPC, Shell & Studies & 2012 & 1 & 7.8 \\
\hline Qatar & $\begin{array}{l}\text { Ras Laffan-expansion } \\
\text { Rasgas IIIi Train 6/7) }\end{array}$ & QGPC, ExxonMobil & Studies & 2009 & 2 & 15.6 \\
\hline Russia & Murmansk (Shtockman) & Gazprom, ConocoPhillip & Studies & 2015 & 2 & 12 \\
\hline Trinidad & Point Frotin-Trains. 5 \& 6. & BP, BG, Repsol, NGC & Studies & & 2 & 10.4 \\
\hline U.S.A & Alaska & Alaska North Slope & Studies & & & \\
\hline Venezuela & $\begin{array}{l}\text { Gran Mariscal de Ayacucho } \\
\text { (Mariscal Sucre) }\end{array}$ & PDVSA, Shell, Mitsubishi & Studies & 2009 & 1 & 4.7 \\
\hline Yemen & Bal-Haf (Yemen LNG) & $\begin{array}{c}\text { Total, Yemen Gas, } \\
\text { Hunt Oil, SK Corp, Hyundai }\end{array}$ & $\begin{array}{l}\text { Impending } \\
\text { EPC }\end{array}$ & 2008 & 2 & 6.8 \\
\hline
\end{tabular}


Table 2. Existing liquefaction terminals worldwide [6].

\begin{tabular}{|c|c|c|c|c|c|c|c|}
\hline \multicolumn{8}{|c|}{ Existing Liquefaction Terminals } \\
\hline \multirow[b]{2}{*}{ Country } & \multirow[b]{2}{*}{ Location } & \multirow[b]{2}{*}{ Shareholders } & \multirow[b]{2}{*}{ Start up } & \multicolumn{2}{|c|}{ Liquefaction } & \multicolumn{2}{|c|}{ Storage } \\
\hline & & & & $\begin{array}{l}\text { No. of } \\
\text { Trains }\end{array}$ & $\begin{array}{c}\text { Capacity } \\
\text { (nominal Mtpa) }\end{array}$ & $\begin{array}{l}\text { No. of } \\
\text { Tanks }\end{array}$ & $\begin{array}{c}\text { Total } \\
\text { Capacity } \mathbf{m}^{3}\end{array}$ \\
\hline \multirow{3}{*}{ Malaysia } & $\begin{array}{c}\text { Bintulu } \\
\text { (Malayisa LNG) }\end{array}$ & Petronas, Shell & 1983 & 3 & 8.0 & 4 & 260,000 \\
\hline & $\begin{array}{c}\text { Bintulu } \\
\text { (MLNG Dua) }\end{array}$ & Sarawak Govt, Mistubishi & 1995 & 3 & 8.0 & 1 & 65,000 \\
\hline & $\begin{array}{c}\text { Bintulu } \\
\text { (MLNG Tiga) }\end{array}$ & $\begin{array}{l}\text { Petronas, Shell, Sarawak Govt, } \\
\text { Mistubishi, Nippon Oil }\end{array}$ & 2003 & 2 & 6.8 & 1 & 120,000 \\
\hline \multirow{3}{*}{ Nigeria } & \multirow{3}{*}{$\begin{array}{l}\text { Bonny Island } \\
\text { (Nigeria LNG) }\end{array}$} & \multirow{3}{*}{ NNPC, Shell Total, Agip } & 1999 & 2 & 6.4 & 2 & 168,400 \\
\hline & & & 2002 & 1 & 3.2 & 1 & 84,200 \\
\hline & & & 2005 & 2 & 8.2 & & \\
\hline Oman & $\begin{array}{c}\text { Qalhat } \\
\text { (Oman LNG) }\end{array}$ & $\begin{array}{l}\text { Oman Govt, Shell, Total, } \\
\text { Korea LNG Mitsubishi, } \\
\text { Mitsui, Partex and Itochu }\end{array}$ & 2000 & 2 & 7.4 & 2 & 240,000 \\
\hline \multirow[t]{4}{*}{ Peru (3) } & $\begin{array}{l}\text { Pampa Melchorita } \\
\text { (Camisea LNG) }\end{array}$ & $\begin{array}{l}\text { Hunt Oil, Sk Corporation, } \\
\text { (Repsol to Join) }\end{array}$ & 2009 & 1 & 4 & & \\
\hline & $\begin{array}{l}\text { Ras Laffan } \\
\text { (Qatargas) }\end{array}$ & $\begin{array}{l}\text { QGPC, ExxonMobil, } \\
\text { Kogas Itochu \& LNG Japan }\end{array}$ & 1996 & 3 & 9.5 & 4 & 340,000 \\
\hline & $\begin{array}{l}\text { Ras Laffan } \\
\text { (Ras Gas) }\end{array}$ & QGPC, ExxonMobil & 1999 & 2 & 6.6 & & 420,000 \\
\hline & Ras Gas Ras Gas II & $\begin{array}{l}\text { QGPC ExxonMobil, } \\
\text { Total, Marubeni, Mitsui }\end{array}$ & & 1 & 4.7 & & \\
\hline \multirow[t]{4}{*}{ Qatar } & Ras Gas II & $\begin{array}{l}\text { QGPU, ExxonMobil, Kogas, } \\
\text { Itochu \& LNG Japan }\end{array}$ & & 1 & 4.7 & & \\
\hline & RasGasIII-T6 (2) & Qatar Petroleum, ExxonMobil & & 1 & 7.8 & & \\
\hline & RasGas III-T7 (2) & Qatar Petroleum, ExxonMobil & & 1 & 7.8 & & \\
\hline & QatarGas III & $\begin{array}{l}\text { Qatar Petroleum, Petroleum, } \\
\text { ConocoPhillips Mitsui }\end{array}$ & & 1 & 7.8 & & \\
\hline \multirow{3}{*}{ Russia } & Sakhalin & Shell, Gazprom, Mitsui & & 2 & 9.6 & & 200,000 \\
\hline & (Sakhalin Energy) & Mitsubishi (Gazprom to to join) & & & & & \\
\hline & & & 1999 & 1 & 3.2 & & 204,000 \\
\hline \multirow{3}{*}{$\begin{array}{l}\text { Trinidad \& } \\
\text { Tobago }\end{array}$} & Point Fortin & BP, BG, Repsol, Suez, NGC & 2002 & 1 & 3.2 & & 160,000 \\
\hline & (Atlantic LNG) & BP, BG, Repsol & 2003 & 1 & 3.2 & & \\
\hline & & & 2005 & 1 & 5.2 & & \\
\hline \multirow{2}{*}{$\begin{array}{l}\text { Abu Dhabi } \\
\text { (USE.) }\end{array}$} & & \multirow{2}{*}{ ADNOC, Mitusi, BP, Total } & 1977 & 1 & 3.2 & & 240,000 \\
\hline & & & 1994 & 2 & 2.5 & & \\
\hline USA & & ConocoPhilips, Marathon Oil & 1969 & 1 & 1.4 & 3 & 108,000 \\
\hline Yemen & Iran Pars & $\begin{array}{c}\text { Total, Yemen Gas, } \\
\text { Hunt Oil, Sk Corp, Hyundai }\end{array}$ & 2009 & & 10 & 2 & 250,000 \\
\hline
\end{tabular}

Notes: In Nov 2005, Fugro Survey Pty Ltd. successfully completed the first phase of contract for sub-sea survey work. Subsidiaries of Fluor Corporation have been awarded a contract by RasGas 3 to provide the initial phase of engineering, procurement and construction management services for RasGas' Common Offplot Project in Qatar. In November, 2005, Peru LNG announced that the project was moving ahead as per the schedule. 
Table 3. Liquefaction terminals under construction worldwide [6].

\begin{tabular}{|c|c|c|c|c|c|c|c|c|}
\hline \multicolumn{9}{|c|}{ Liquefaction Terminals under Construction } \\
\hline & \multirow[b]{2}{*}{ Country } & \multirow[b]{2}{*}{ Location } & \multirow[b]{2}{*}{ Shareholder } & \multirow{2}{*}{$\begin{array}{c}\text { Start } \\
\text { up }\end{array}$} & \multicolumn{2}{|c|}{ Liquefaction } & \multicolumn{2}{|c|}{ Storage } \\
\hline & & & & & $\begin{array}{l}\text { No. of } \\
\text { Trains }\end{array}$ & $\begin{array}{c}\text { Capacity } \\
\text { (Nominal) Mtpa }\end{array}$ & $\begin{array}{l}\text { No. of } \\
\text { Tanks }\end{array}$ & $\begin{array}{c}\text { Total } \\
\text { Capacity } \mathbf{m}^{3}\end{array}$ \\
\hline 1 & Egypt & $\begin{array}{c}\text { Idku } \\
\text { (Egyptian LNG ) }\end{array}$ & $\begin{array}{l}\text { EGPC, EGAS, BG, Gas } \\
\text { de France, Petronas }\end{array}$ & 2006 & 1 & 3.6 & & \\
\hline 2 & $\begin{array}{l}\text { Equatorial } \\
\text { Guinea }\end{array}$ & Bioko Island & Marathon, GEPetrol & 2007 & 1 & 3.4 & 2 & 272,000 \\
\hline 3 & Indonesia & Irian Jaya (Tangguh) & $\begin{array}{l}\text { Bp, MI Berau, CNOOC, } \\
\text { Nippon Oil, LNG Japan }\end{array}$ & 2008 & 2 & 7.6 & & \\
\hline 4 & Nigeria & $\begin{array}{c}\text { Bonny Expansion-Nigeria } \\
\text { LNG) }\end{array}$ & $\begin{array}{c}\text { NNPC, Shell, NLNG } \\
\text { Plus } 4 \text { \& } 5 \text { Total, Eni Train } 6\end{array}$ & 2007 & 1 & 4.1 & & \\
\hline 5 & Norway & $\begin{array}{l}\text { Melkoya Island } \\
\text { (snohvit j. v) }\end{array}$ & $\begin{array}{c}\text { Station, total Gaz de France, } \\
\text { Norsk Hydro }\end{array}$ & 2007 & 1 & 4.2 & 2 & 280,000 \\
\hline 6 & Oman & $\begin{array}{l}\text { Qalhat-exp. } \\
\text { (Qalhat LNG) }\end{array}$ & $\begin{array}{c}\text { Oman Govt., Oman LNG, } \\
\text { Union fenosa }\end{array}$ & 2006 & 1 & 3.5 & & \\
\hline 7 & Qatar & $\begin{array}{l}\text { Ras Laffan-exp. } \\
\text { (Ras Gas II) } \\
\text { Ras Laffan-exp }\end{array}$ & QGPC, ExxonMobil Train 5 & 2007 & 1 & 4.7 & & \\
\hline 8 & & (Quatargas II) & QGPC, ExxonMobil, Total 4 & 2008 & 1 & 7.8 & & \\
\hline 9 & Russia & $\begin{array}{c}\text { Sakhain } \\
\text { Sakhain Energy) }\end{array}$ & Shell, Mitsui, Mitsubishi & 2007 & 2 & 9.6 & 2 & 200,000 \\
\hline
\end{tabular}

Note: LNG peaks having plants and small scale plants serving satellites are not included.

invasions. [7] has pointed out that generally, industries in rural areas have been implicated for the introduction of new population of non-indigenous construction laborers and management staff, may enable the introduction of new land seeking cultivators, immigrants, inflationary trends, new diseases, high crime rate, increased noise level from motorized equipments and other heavy duty vehicles, alcoholism, prostitution, disregard for local culture and dissemination of alien ideas and information. The presence of construction crews and non-indigenous workers may also increase local population which can make high demand on existing infrastructural facilities. Such outcomes are better managed through pre-project environmental Impact Assessment.

Pre-project socio-economic impact studies, especially the baseline data collection by [8] in the Bayelsa and Rivers states areas of the Niger Delta, covering Ogbogolo (Enwhe), Edeoha, Owerewere, Egbebiri (biseni), Ikata, Ula-okobo, Ukpeliede, Akara-Olu, Ula-Ikata, Edeoha, Odiereke-Ubie, Otuokpoti, Akinma, Oyigba, Okogbe, Ozochi, Ibelebiri, Aminigboko, Akala-mini, Ihuowo, Ebrass, Oruama, Oshika, Azikoro/Yenagoa, Oruama, Odau, Egunughau, Azikoro, Oruma, Edagbeni/Betterland, Akara-Olu, Ogoda, Biseni, Ula-Ikatu, Obedum, Odhiougbokor, Ozochi, Ubeta, Idu, Alaokobo, Idu Ekpeye etc. has been of significant importance in the proactive assessment of the possible negative and/or positive consequences of a few trains and nodes of the Integrated Oil and Gas Project (IOGP) in the volatile Niger Delta area of Nigeria. This report by [8] contributed largely in the emergence of the Environmental Impact Assessment Final Report by [9].

The transportation, processing and distribution of NLNG raw materials and finished products are thus, most likely to generate beneficial and/or non-beneficial socio-economic activities in the immediate host and distance communities. The case of commercial logging crews for instance, may not be directly similar to the pioneering, NLNG project construction, but both however, have operational crews and focuses on the exploitation of natural resources in rural and relatively isolated communities. The likes of [7] [10] [11] have concluded that industries depending on natural resources and operating in rural areas have the potentials of affecting the environment and rural households' livelihood and other socio-economic activities, negative and/or positively.

One of the strategies for overcoming resentments emanating from resource utilization resulting in environmental degradation is the amelioration of the negative consequences through what is now commonly known as "Corporate Social Responsibility (CSR)". This invariably is founded and guided by the outcome of the Environmental Management Plan (EMP). 


\section{Corporate Social Responsibility (CRS) Concept in Petroleum Resources Development and Management}

Corporate Social Responsibility (CSR), also referred to as Corporate Conscience (CC), Corporate Citizenship (CC), Social Performance (SP), or Sustainable Responsible Business (SRB) is describable as a form of corporate self-regulation, which is integrated into a business model. CSR policy functions is a corporate built-in, self-regulating system through which business monitors and ensures that it actively comply with the stipulated laws, ethical standards, as well as international norms. The main objective of CSR is to enhance responsibility for the company's activities in the host communities and promote desirable impacts of the activities in the environment. It's also vital for moderating the effects of negative impacts on consumers, employees, host communities, including other stakeholders [12].

Also, CSR-focused businesses are devoted to encourage public interest by encouraging community prosperity and development, while strategically discouraging such outcomes which are detrimental to the public, irrespective of legality or justifiability. CSR is thus better perceived as the strategically planned incorporation of the consequences of corporate activities on the public into corporate decision-making, based on a tripartite effort to consider the wellbeing of the people, the earth planet, and profit accruing to the company [12].

\section{Study Area}

The study area is Bonny Local Government Area (L.G.A) (which covers the whole of Bonny Island and mainland area) and is located about 40 kilometers to the south-eastern part of Port Harcourt, which is the state capital. Bonny Island (which is a major study focus area) is located on the outer southern section of the Niger Delta complex. It's a trapezoid shaped landmass with the following co-ordinates: Northwestward Latitude $4^{\circ} 33^{\prime} \mathrm{N}$ and Longitude $7^{\circ} 08^{\prime} \mathrm{E}$ : North eastward Latitude $4^{\circ} 30^{\prime} \mathrm{N}$ and Longitude $7^{\circ} 20^{\prime} \mathrm{E}$ : Southwestward Latitude $4^{\circ} 22^{\prime} \mathrm{N}$ and Longitude $7^{\circ} 20^{\prime} \mathrm{E}$; Southwestward Latitude $4^{\circ} 22^{\prime} \mathrm{N}$ and Longitude $7^{\circ} 08^{\prime} \mathrm{E}$ [13]. Bonny L.G.A comprises of Bonny Island and the outlying mainland areas around it.

Bonny Island is mostly surrounded by the Atlantic Ocean and has a population of about 170,000 people. Figure 1 presents a map of Rivers State, showing Bonny LGA), while Figure 2 shows the map of Bonny Island, (including the outlying lands, adding together to form the local government area). The considered communities for study include Finima, Banigo, Greens, Jumbo, Peterside, Epelema, Dema, Fibiri, Kalibiama, Oloma, Bonny, Iyoba, Kruma, Abalamabie, Banigo Akiama, Peterside, Borokiri and Borokiri.

\section{Population and Socio-Economic Activities}

The socio-economic activity is largely extractive. The indigenous population depends on fishing for their subsistence, but also engages in small-scale agriculture by cultivating some domestic crops such as cassava, yam, coconut and plantain. The discovery of oil and gas has helped to diversify the socio-economic activities of the people and improved the economic and administrative importance of the island.

There are now civil servants that work in local government offices and administrative as well as management level employees and laborers who are employed to work in Natural Gas Processing Plant (NGPP) on Bonny Island. The influx of workers for the Base and Expansion projects construction and associated traders and service workers placed pressure on accommodation and services on Bonny Island.

The population of Bonny is difficult to determine as there are numerous estimates. It was put at 67,254 persons, while the population of Rivers state was established in the 2006 census at 5.2 million. For crude oil and natural gas exploitation respectively Shell Petroleum Development Company (SPDC) and Nigeria LNG Limited became major players, and to a lesser extent, Mobil Nigerian Producing Unlimited (MNP) [14].

The main population Centre on Bonny Island is Bonny Town some $5 \mathrm{~km}$ from the NLNG plant site. Based on another estimate (1991 Census), Bonny Town, New Finima and Bonny Local Government Area (LGA) as a whole had populations of 22,989, 5,590 and 76,124 people, respectively. Bonny Town alone accounted for about $30 \%$ of the LGA's population, while Finima contributed about 7.3\%) [14].

At the peak of NLNG's Base project construction in 1998-9, over 17,500 construction workers (excluding dependants) were present on Bonny Island. With the influence of NLNG and other companies, it is likely that Bonny Town and New Finima, now account for higher proportions of the LGA's population [14]. Notably [13] has also indicated that based on the 1991 census the estimated population of Bonny L.G.A was 76,412 persons. 


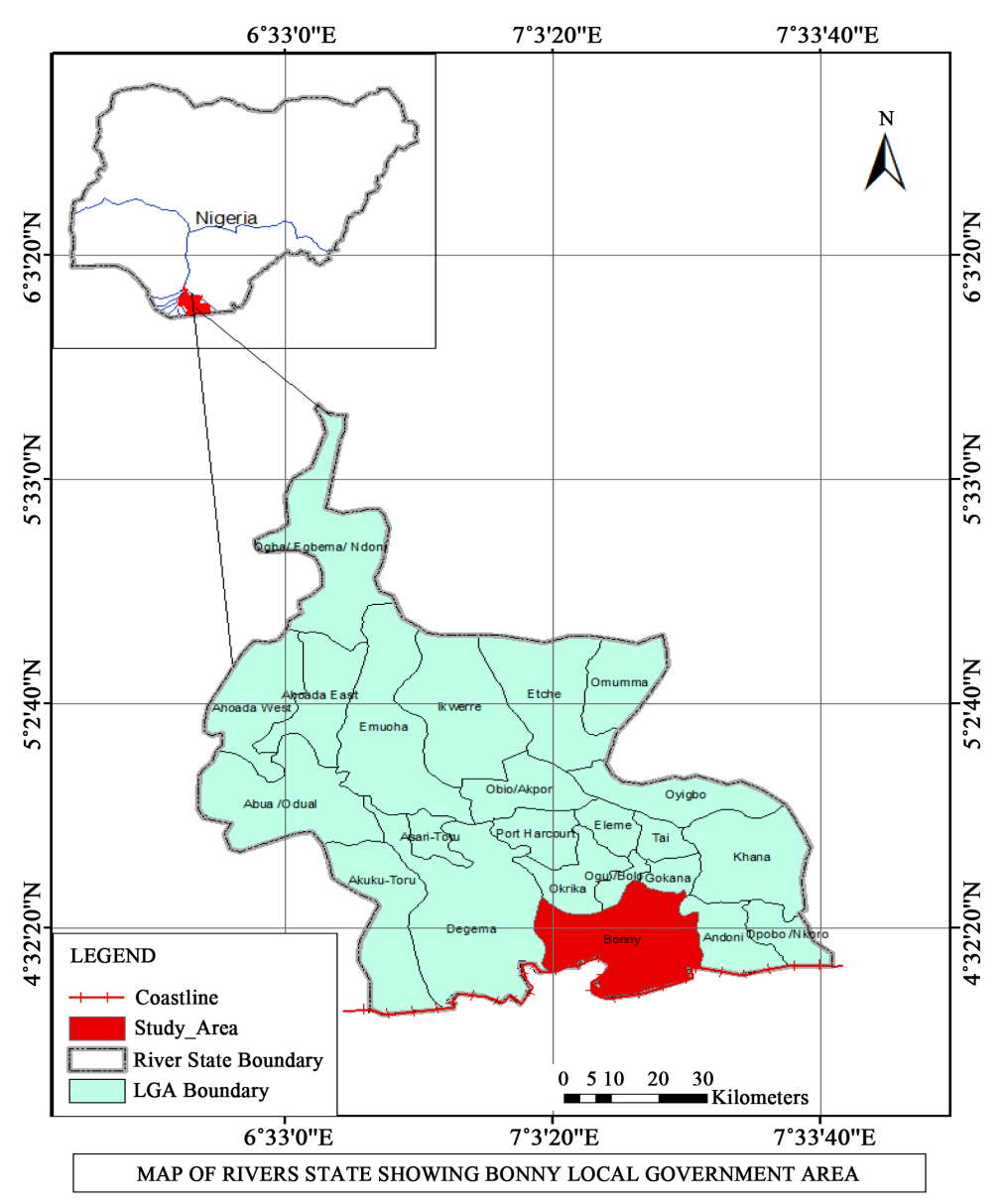

Figure 1. Map of rivers state showing bonny local government area.

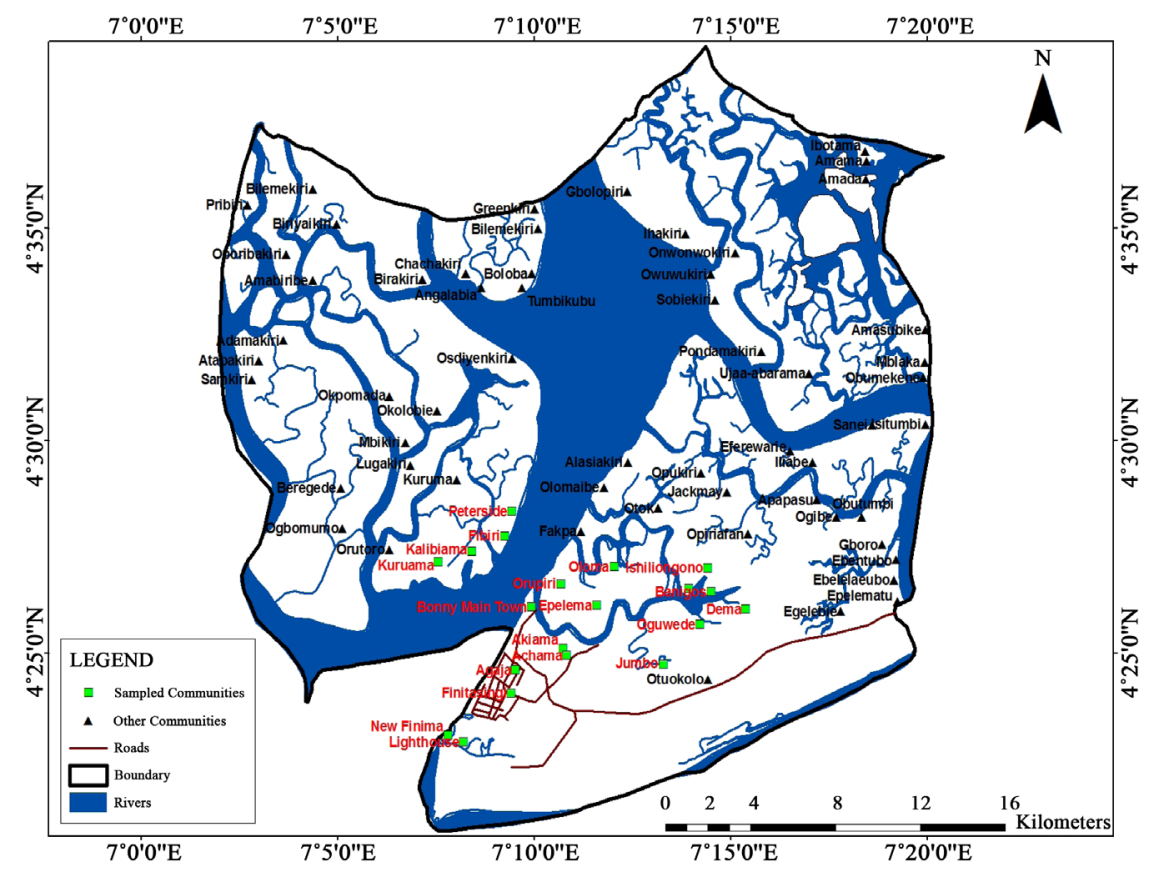

Figure 2. Map of bonny local government area showing sampled communities. 


\section{Methods}

Both primary and secondary data were utilized for this study. The survey research method was adopted, in obtaining primary data from the communities. Visits and study exercises were carefully planned due to the water logged terrain and remote nature of some communities. Primary data were collected using open ended questionnaire, Checklists, Focused Group Discussions (FGDs) and Key Informant Interviews (KIIs). Secondary data were collected mainly from NLNG publications. Transect Walks (TWs) and Participatory Transects (PTs) were also used. Data were collected from communities listed in the sample framework in Table 4. This study is largely based on the review of related literature and on data presented in literature, including Nigeria LNG Ltd. publications [15]-[21].

Table 4. Sample framework.

\begin{tabular}{|c|c|c|c|c|c|c|}
\hline $\mathbf{S} / \mathbf{N}$ & Name of community & $\begin{array}{l}\text { Number of } \\
\text { respondents } \\
\text { sampled }\end{array}$ & $\begin{array}{l}\text { Number of } \\
\text { questionnaires } \\
\text { returned }\end{array}$ & $\begin{array}{c}\text { Number of } \\
\text { well filled } \\
\text { questionnaires } \\
\text { returned }\end{array}$ & $\begin{array}{l}\text { Percentages of } \\
\text { questionnaires } \\
\text { returned }\end{array}$ & $\begin{array}{l}\text { Percentages of } \\
\text { well filled } \\
\text { questionnaires } \\
\text { used in study }\end{array}$ \\
\hline 1 & $\begin{array}{c}\text { NEW FINIMA } \\
\text { (On the Island and Primary Host) }\end{array}$ & 242 & 225 & 221 & 93.00 & 91.32 \\
\hline \multirow[t]{2}{*}{2} & $\begin{array}{l}\text { BANIGOS (On the Island and } \\
\text { A village under Bonny LGA) }\end{array}$ & 35 & 22 & 22 & 62.85 & 62.85 \\
\hline & BONNY MAIN TOWN (On the Island) & 803 & 785 & 782 & 97.76 & 97.38 \\
\hline 3 & $\begin{array}{l}\text { OGWEDE (On the Island and a village } \\
\text { under Bonny Local Government) }\end{array}$ & 24 & 14 & 14 & 58.33 & 58.33 \\
\hline 4 & ACHAMA(On the Island ) & 35 & 29 & 26 & 82.86 & 74.29 \\
\hline 5 & $\begin{array}{c}\text { ISHILIONGON } \\
\text { (In Eastern part of Bonny Island, } \\
\text { Separated by water But within } \\
\text { Bonny Local Government ) }\end{array}$ & 25 & 24 & 18 & 96.00 & 72.00 \\
\hline 6 & $\begin{array}{c}\text { AGAJA } \\
\text { (Around Finima and a fishing port) }\end{array}$ & 65 & 61 & 57 & 93.84 & 87.69 \\
\hline 7 & $\begin{array}{l}\text { FINITASINGI } \\
\text { (Around Finima) }\end{array}$ & 23 & 21 & 21 & 91.30 & 91.30 \\
\hline 8 & LIGHT HOUSE (Around Finima) & 30 & 27 & 25 & 90.00 & 83.33 \\
\hline 9 & JUMBO (On Bonny Island) & 30 & 25 & 22 & 83.33 & 73.33 \\
\hline 10 & $\begin{array}{c}\text { PETERSIDE } \\
\text { (Wetern Axis across the River }\end{array}$ & 108 & 106 & 101 & 98.15 & 93.51 \\
\hline 11 & $\begin{array}{c}\text { EPELEMA } \\
\text { (Not on Island, but on eastern axis) }\end{array}$ & 25 & 22 & 20 & 88.00 & 80.00 \\
\hline 12 & DEMA (Eastern Axis) & 15 & 10 & 09 & 66.66 & 60.00 \\
\hline 13 & $\begin{array}{c}\text { ORUPIRI } \\
\text { (GTS Community in Bonny LG) }\end{array}$ & 10 & 9 & 05 & 90.00 & 50.00 \\
\hline 14 & KALIBIAMA (Western Axix) & 45 & 44 & 42 & 97.77 & 95.45 \\
\hline 15 & OLOMA (Eastern Axis) & 60 & 58 & 53 & 96.66 & 88.33 \\
\hline 16 & FIBIRI (Western Axis) & 25 & 24 & 20 & 96.00 & 80.00 \\
\hline 17 & KURUMA (Western Axis) & 190 & 177 & 167 & 93.15 & 87.89 \\
\hline 18 & ABALAMABIE (On Bonny Island) & 175 & 166 & 162 & 94.86 & 92.57 \\
\hline \multirow[t]{2}{*}{19} & AKIAMA (On Bonny Island) & 202 & 197 & 193 & 97.52 & 95.54 \\
\hline & TOTAL & 2167 & 2046 & 1980 & 94.41 & 91.37 \\
\hline
\end{tabular}




\section{Results and Discussions}

\subsection{Developmental Programmes by NLNG}

The available literature, published data, participatory transect walks (PTWs), key informant interviews (KIIs) and focused group discussion FGDs) shows that the Nigeria LNG Ltd. has provided several socio-economic development programmes, and constructed several physical infrastructures. Some example of such programs provided include the following:-- Bonny Educational Endowment Fund (BEEF), The Nigeria Prizes for Science and Literature, Bonny Vocational Center and Educational Programmes (Table 5: shows the courses available at the Bonny Vocational Center), Youth Empowerment Scheme (YES), Micro-Finance Scheme/Thrift and Loan schemes by NLNG project, (vi) Business Development/Advisory Support Services, Bonny Utilities Company (GUC), Right of Way Maintenance Contract for community members, Nigeria LNG Limited's Direct employment, Taxes and Duties to Government, Other infrastructural facilities provided by the NLNG and some by Joint Industry Companies (JIC).

There are a number of projects claimed to have been provided by the NLNG project, from which the host communities of the project have benefitted. Some of these includes specific community projects provided singularly by NLNG and some in collaboration with the Joint Industry Companies (JIC), comprising of NLNG, SPDC and Mobil. Tables 6-11, present specific community projects accompanying each stages of the NLNG project.

The roles of the Nigeria LNG Limited in Public Health Management (PHM) appear to be diverse. For instance [22] and [23] have highlighted the contributions of the Nigeria LNG Limited to health development as part of its corporate responsibility programmes in the operational areas, including administration of the pharmaceutical drug "Combantrin" for deworming and provision of an Electrocardiogram (ECG) Machine respectively. [22] also noted that "referral cases from Bonny General Hospital to other secondary and tertiary health centres in Port Harcourt will reduce considerably, with the donation of an electrocardiogram (ECG) machine to the hospital by the NLNG Residential Area Ladies Association”.

\section{Table 5. Available courses at Bonny Vocational Center (BVC) [20].}

\begin{tabular}{|c|c|}
\hline $\mathrm{S} / \mathrm{N}$ & Description of Area Of Specialization \\
\hline 1 & Civil Engineering \\
\hline 2 & Mechanical Engineering Skill \\
\hline 3 & Electrical Engineering \\
\hline 4 & Food Preparation and Culinary Arts \\
\hline 5 & Food and Beverage Service \\
\hline 6 & Reception Operations and Services \\
\hline 7 & Business and Administration \\
\hline 8 & Computing \\
\hline 9 & Teaching, Training and Assessing Learning \\
\hline 10 & Procurement Administration \\
\hline 11 & Project Administration \\
\hline 12 & Instrumentation \\
\hline 13 & Welding and Fabrication \\
\hline 14 & Metal Machining \\
\hline 15 & Site Scaffolding \\
\hline 16 & Rigging \\
\hline 17 & First Aid programme \\
\hline
\end{tabular}


Table 6. Specific community projects accompanying train three (3) of the NLNG Project [20].

\begin{tabular}{cc}
\hline S/N & Description of Projects \\
\hline 1 & The Bonny Vocational Centre \\
2 & Construction of Coal Beach Roundabout \\
3 & Rehabilitation of road to Finima \\
4 & Rehabilitation of Court Road \\
5 & Rehabilitation of Lecox/Isowari Road \\
6 & Rehabilitation of New Layout and King Jaja Road \\
7 & Rehabilitation of road to Vocational Training School \\
8 & Rehabilitation of Park Road \\
9 & Rehabilitation of Government School Hospital Road By-pass \\
10 & Rehabilitation of King Perekule Road. \\
\hline
\end{tabular}

Table 7. Specific community projects accompanying trains four and five (4 and 5) and NLNGPlus [20].

\begin{tabular}{cc}
\hline S/N & Description of Projects \\
\hline 1 & Construction of Bonny Sandy Road \\
2 & Bonny Land Reclamation \\
3 & Finima Soccer Field Upgrade \\
4 & Finima Land Reclamation \\
5 & General Road Repairs in Finima. \\
\hline
\end{tabular}

Table 8. Specific community projects accompanying train 6 (NLNGSix) [20].

\begin{tabular}{cc} 
S/N & Description of Project \\
\hline 1 & Jerusalem Road Extension \\
2 & $\begin{array}{c}\text { Bonny Land Reclamation Shore Protection in Bonny Bonny Housing Estate } \\
\text { Project Finima Fitness Centre Finima Truck Park Finima Road Repairs }\end{array}$ \\
\hline
\end{tabular}

Table 9. Intervention projects for provision of portable water to host communities [20].

\begin{tabular}{cc} 
S/N & Description of Project \\
\hline 1 & Drilling of second backup borehole complete with well pump in Bonny \\
3 & Deticulation of water distribution network to the new developing areas in Bonny \\
4 & Repair of two collapsed boreholes with the capacity of 45,000 liters per hour in Finima \\
6 & Construction of water tanker loading bay at Bonny and Finima water treatment plants \\
& to improve tanker delivery to the community
\end{tabular}


Table 10. Key figures of the bonny electricity company (as at November 2009) [20].

\begin{tabular}{cc}
\hline S/N & Description \\
\hline 1 & Supply capacity: NLNG: 12.5 MVA,SPDC: 10MVA \\
2 & 40 low voltage distribution transformer substations \\
3 & Over 500 high voltage concrete poles \\
4 & Over 2000 low voltage concrete poles \\
5 & Two 11 kilovolt (KV) injection substations \\
6 & Energized: 9080 households \\
7 & Availability: $98.7 \%$ six months average \\
8 & Consumption: 6300 MWh/month \\
9 & Peak load: 12.7 MVA \\
10 & LTI recorded: none @ 2, 203, 711 hours \\
11 & Workforce: $94 \%$ Bonny indigenes \\
\hline
\end{tabular}

Table 11. Host communities’ benefits from empowerment programmes [20].

\begin{tabular}{cc}
\hline S/N & Description of host communities benefits \\
\hline 1 & Increased commercial activities spurred by infusion of capital and new skills. \\
2 & Reduced poverty level \\
3 & Integrated financial and technical services to small businesses \\
4 & Creation of avenues for self-employment, plus reduced dependency \\
5 & Encouragement of savings and entrepreneurial habits \\
6 & Training and capacity building. \\
\hline
\end{tabular}

[23] reported the involvement of the NLNG Limited in the deworming of over two hundred pupils of public schools in Rumiji, Rivers states, Nigeria. The once in every three months deworming activity is part of the NLNG's Deworming Programme (NLNG-DP). Some of the hosts and pipeline communities which have benefitted include Bonny and part of Ogbo in Ahoada East Local Government Area of Ekpeye Kingdom, as well as Ogba, Kalabari and Emohua communities. The deworming activities were carried out in collaboration with Neimeth Pharmaceuticals, Lagos, Rivers State Health Ministry, Local Government and Community Health Officials.

Table 12 highlights the contributions of Nigeria LNG Limited to HIV/AIDS prevention and management [20]. Other contributions include the implementation of a study of knowledge, attitude and practice; training of Health Peer Educators (HPEs) who are reservoirs and promulgators of social knowledge; Carried out campaigns aimed at influencing various groups on health related issues; established Youth Against AIDS Clubs in secondary schools; and campaigns to improve public acceptance and interpersonal relationship with persons living with AIDS.

Plate 1 shows socio-economic contributions of the Nigeria LNG Ltd. in Bonny Local Government Area. Also, the Nigeria LNG Ltd. for years has provided, medium sized ferries to transport indigenes/non-indigenes of host communities from Bonny Island to Port Harcourt at least twice each week for free, while at the inception of the NLNG planning, selected community opinion leaders were flown overseas to experience the likely developmental activities that could be triggered off by an LNG project in their communities. Table 13 presents the comparative communities ranking based on level of satisfaction on socio-economic development in the Sampled Communities.

Table 14 conveys respondents' perception of the level of contribution of institutions and individual donors to 


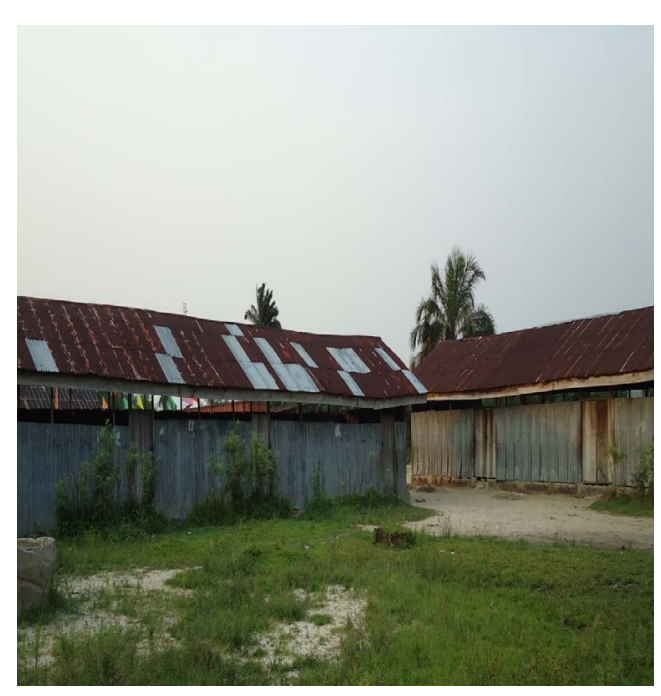

(a)

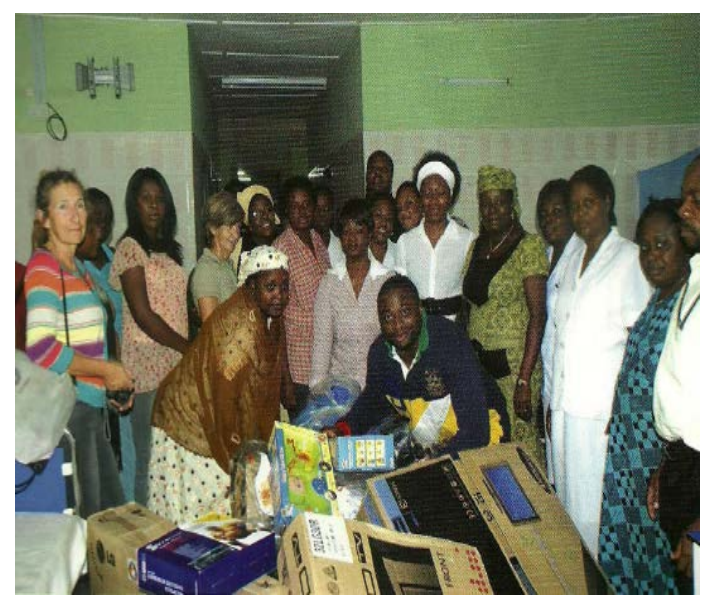

(c)

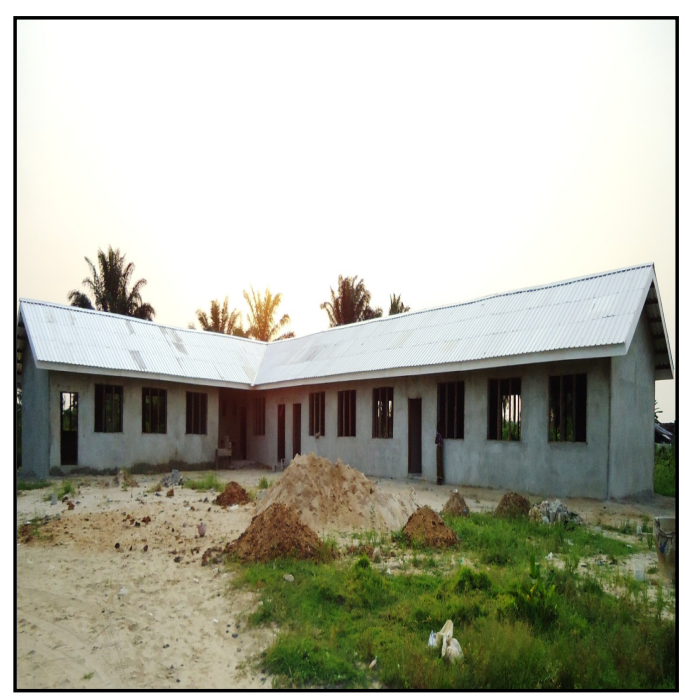

(b)

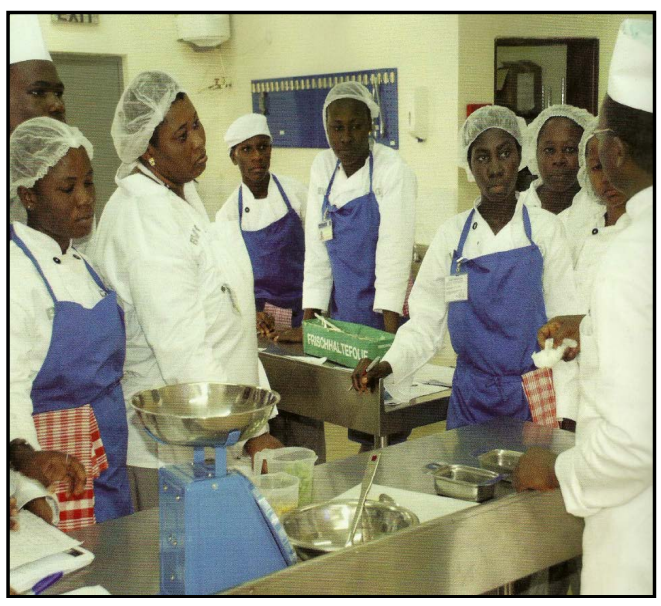

(d)

Plate 1. Socio-economic development contributions of Nigeria LNG limited to host communities. (a) The old primary school building for lighthouse community (field work); (b) The new primary school building being constructed by NLNG residential area women association for lighthouse community (fieldwork); (c) Nigeria LNG residential area ladies making donations of plasma televisions and other vital medical items to the bonny general hospital, bonny town [18]; (d) A section of almost all female students receiving catering instructions from a trainer at the bonny vocational training school [18].

Table 12. Contributions of the Nigeria LNG limited to HIV/AIDS prevention and management in its operational area [20].

\begin{tabular}{cc}
\hline S/N & Description of HIV/AIDS Prevention and Management Activities by NLNG Ltd. \\
\hline 1 & Counselling and testing of 24,256 persons with 1842 individuals testing positive \\
2 & Facilitated HIV treatment for 277 persons \\
3 & Provided HIV/AIDS prevention information to 44,737 persons \\
5 & Formed three Support groups for People Living with HIV/AIDS \\
6 & Trained 57 female sex workers on life skills and another 52 and clients as Peer Educators \\
7 & Carried out capacity building for over 500 healthcare workers, community groups, \\
8 & which includes the clergy, as regards the effective programme implementation and service delivery
\end{tabular}


Table 13. Comparative communities ranking based on level of satisfaction of socio-economic development in sampled communities.

\begin{tabular}{|c|c|c|c|c|c|c|c|c|c|c|}
\hline \multirow{2}{*}{$\mathbf{S} / \mathbf{N}$} & \multirow{2}{*}{ PARTICULARS } & \multicolumn{2}{|c|}{ ADEQUATE } & \multicolumn{2}{|c|}{ INADEQUATE } & \multicolumn{2}{|c|}{ NOT SURE } & \multicolumn{2}{|c|}{ TOTAL } & \multirow{2}{*}{$\begin{array}{l}\text { MOST IMPORTANT } \\
\text { PROVIDER(S) }\end{array}$} \\
\hline & & NO. & $\%$ & NO. & $\%$ & NO. & $\%$ & NO. & $\%$ & \\
\hline 1 & Primary schools & 172 & 8.69 & 1785 & 90.15 & 23 & 1.16 & 1980 & 100 & $\begin{array}{c}\text { NLNG, state government/private, } \\
\text { other multinationals }\end{array}$ \\
\hline 2 & Secondary school & 87 & 4.39 & 1851 & 93.48 & 42 & 2.11 & 1980 & 100 & NLNG, state government/private \\
\hline 3 & Higher/vocational schools & 45 & 2.27 & 1923 & 97.12 & 12 & 0.60 & 1980 & 100 & NLNG/SPDC/OTHERS \\
\hline 4 & $\begin{array}{l}\text { Medical facilities } \\
\text { and treatments }\end{array}$ & 584 & 29.49 & 1361 & 68.74 & 35 & 1.76 & 1980 & 100 & $\begin{array}{c}\text { NLNG/private/government } \\
\text { /NGOs }\end{array}$ \\
\hline 5 & Provided electricity supply & 583 & 29.44 & 1166 & 58.89 & 231 & 11.61 & 1980 & 100 & $\mathrm{JIC}$ \\
\hline 6 & Provided water supply & 341 & 17.22 & 1560 & 78.79 & 79 & 3.97 & 1980 & 100 & JIC \\
\hline 7 & Micro-credit and loans & 72 & 3.64 & 1431 & 72.27 & 477 & 23.97 & 1980 & 100 & NLNG/others \\
\hline 8 & Vocational training & 451 & 22.78 & 1249 & 63.08 & 280 & 14.07 & 1980 & 100 & NLNG and other JIC members \\
\hline 9 & Children immunization & 1532 & 77.37 & 424 & 21.41 & 24 & 1.21 & 1980 & 100 & NLNG/state government \\
\hline 10 & $\begin{array}{l}\text { HIV/AIDS awareness, } \\
\text { prevention and medication }\end{array}$ & 539 & 27.22 & 1210 & 61.11 & 231 & 11.61 & 1980 & 100 & $\begin{array}{l}\text { Mainly NLNG/ includes } \\
\text { state government }\end{array}$ \\
\hline 11 & Roads and communication & 258 & 13.03 & 1602 & 80.91 & 120 & 6.03 & 1980 & 100 & JIC, especially NLNG \\
\hline 12 & $\begin{array}{c}\text { Renovation and } \\
\text { Construction of king/chief } \\
\text { palaces/traditional } \\
\text { monuments }\end{array}$ & 391 & 19.75 & 1316 & 66.46 & 273 & 13.72 & 1980 & 100 & Notably NLNG \\
\hline \multirow[t]{2}{*}{13} & Others & 222 & 11.21 & 1487 & 75.10 & 271 & 13.62 & 1980 & 100 & JIC and Especially NLNG \\
\hline & Total & 5277 & 20.50 & 18,365 & 71.35 & 2098 & 8.15 & 25740 & 100 & N/A \\
\hline
\end{tabular}

Table 14. Communities perception of the level of development activities carried out within the host communities by major multinational petroleum resources developing companies and different tiers of government in bonny LGA.

\begin{tabular}{|c|c|c|c|c|c|c|c|c|c|}
\hline \multirow{2}{*}{$\mathbf{S} / \mathbf{N}$} & \multirow{2}{*}{ PARTICULARS } & \multicolumn{2}{|c|}{ SATISFACTORY } & \multicolumn{2}{|c|}{ UNSATISFACTORY } & \multicolumn{2}{|c|}{ NOT SURE } & \multicolumn{2}{|c|}{ TOTAL } \\
\hline & & NUMBERS & $\%$ & NUMBERS & $\%$ & NUMBERS & $\%$ & NUMBERS & $\%$ \\
\hline 1 & SPDC & 25 & 1.26 & 1876 & 94.7 & 79 & 3.99 & 1980 & 100 \\
\hline 2 & NLNG & 388 & 19.60 & 1548 & 78.18 & 44 & 2.22 & 1980 & 100 \\
\hline 3 & MOBIL & 107 & 5.40 & 1854 & 93.6 & 19 & 0.96 & 1980 & 100 \\
\hline 4 & LOCAL GOVERNMENT & 32 & 1.62 & 1942 & 98.1 & 6 & 0.30 & 1980 & 100 \\
\hline 5 & STATE GOVERNMENT & 11 & 0.56 & 1937 & 97.8 & 32 & 1.62 & 1980 & 100 \\
\hline 6 & $\begin{array}{l}\text { FEDERAL GOVERNMET } \\
\text { Agencies/Ministries } \\
\text { (Excluding NNPC) }\end{array}$ & 5 & 0.25 & 1972 & 99.6 & 3 & 0.15 & 1980 & 100 \\
\hline \multirow[t]{2}{*}{7} & $\begin{array}{l}\text { OTHERS (NGOs, CBOs } \\
\text { and INDIVIDUALS }\end{array}$ & 36 & 1.82 & 1912 & 96.6 & 32 & 1.62 & 1980 & 100 \\
\hline & TOTAL & 304 & 2.19 & 13,341 & 96.26 & 215 & 1.55 & 13,860 & 100 \\
\hline
\end{tabular}

socio-economic development in the study area. Notably NLNG project faired better than all other potential providers.

It appears that SPDC and Mobil Producing Nigeria have wider areas of operation in the Niger Delta areas than Nigeria LNG Ltd. Consequently, it appears that the Nigeria LNG Ltd. has been able to focus largely at the 
not so equally widespread host and gas pipelines traversed communities in its community development activities.

\subsection{Other Positive Consequences}

Traverse walks within communities showed that in New Finima Community, the Nigeria LNG Ltd. provided a Sports Arena, Traditional ruler's palace, Burial ground fencing and gate, Bakery for women, one orthodox Church building and one Cherubim and Seraphim Aladura (white garment) Church building, a town hall provided by TSJK (Contractors to NLNG) as well as roads and New Finima Traditional ruler's palace. Some respondents, indicated that Nigeria LNG Ltd. paid and facilitated the exhumation and relocation of Finima Community traditional rulers' buried remains, from Old Finima to the New Finima burial site, where presently, the new graves could be seen, during this study.

In Bonny town, these include schools, extension of Bonny King's palace, Big Market and so on. Also the NLNG has provided assistance in the area of medical buildings and facilities provision, as well as direct employment and regular payment of relevant personnel. During the NLNG project base project construction Nigeria LNG Ltd. disbursed financial incentives to school teachers to discourage them from abandoning the class rooms in order to work as laborers, for the purpose of earning "extra" incomes [24].

\subsection{Negative Consequences of NLNG Activities}

The relocation of the indigenous people of Old Finima (traditionally living by the water side), and which initially populated the present site of the NLNG plant, has cultural implications. Focused Group Discussions (FGDs) and Key Informant Interviews (KIIs), especially within New Finima, revealed a high sense of loss, characterized by "a forced deprivation of contact with a "Sense of Well-being" and "Not dwelling within the traditional sphere of historical atmosphere" as summarized by a respondent. Table 15: presents data collected, based on respondents' perception of pattern of negative consequences of the NLNG project, right from the NLNG Base project construction stage in 1993 to the last train construction on the household members in Bonny LGA.

Focus Group Discussions and Key Informant Interviews also indicated that efforts, to provide replacement residential buildings to families, now in New Finima by Nigerian National Petroleum Corporation (NNPC) on behalf of NLNG, which are structurally better than those originally at Old Finima, and evidently have better

Table 15. Negative consequences of the Nigeria liquefied natural gas on households in bonny local government area.

\begin{tabular}{|c|c|c|c|c|c|c|c|c|c|}
\hline \multirow{2}{*}{$\mathbf{S} / \mathbf{N}$} & \multirow{2}{*}{ Type of impact } & \multicolumn{2}{|c|}{ Yes } & \multicolumn{2}{|c|}{ No } & \multicolumn{2}{|c|}{ Not sure } & \multicolumn{2}{|c|}{ Total } \\
\hline & & Freq. & $\%$ & Freq. & $\%$ & Freq. & $\%$ & Freq. & $\%$ \\
\hline 1 & Increased Inflation of household commodities price & 121 & 6.11 & 674 & 34.04 & 1185 & 59.85 & 1980 & 100 \\
\hline 2 & $\begin{array}{l}\text { Increase in marital relations breakdown } \\
\text { of indigenes/non indigenes }\end{array}$ & 23 & 1.16 & 833 & 42.07 & 1124 & 56.77 & 1980 & 100 \\
\hline 3 & Increase in house rent & 734 & 37.07 & 453 & 22.88 & 793 & 40.05 & 1980 & 100 \\
\hline 4 & Increased threat to family cohesion & 193 & 9.75 & 956 & 48.28 & 831 & 41.97 & 1980 & 100 \\
\hline 5 & $\begin{array}{l}\text { Increase in pressure on existing residential } \\
\text { household facilities by non-indigenous NLNG staff }\end{array}$ & 202 & 10.20 & 377 & 19.04 & 1401 & 0.76 & 1980 & 100 \\
\hline 6 & Introduction of alien ideas and cultures to household members & 323 & 16.31 & 845 & 42.68 & 812 & 41.01 & 1980 & 100 \\
\hline 7 & Increase in household waste generation by immigrants & 212 & 10.71 & 882 & 44.55 & 886 & 44.75 & 1980 & 100 \\
\hline 8 & $\begin{array}{l}\text { Increased household members involvement } \\
\text { in violent Demonstration }\end{array}$ & 779 & 39.34 & 237 & 11.97 & 964 & 48.69 & 1980 & 100 \\
\hline 9 & $\begin{array}{l}\text { Increased household members } \\
\text { involvement in criminal activities }\end{array}$ & 12 & 0.61 & 1423 & 71.87 & 45 & 27.53 & 1980 & \\
\hline \multirow[t]{3}{*}{10} & Household members involvement in prostitution & 1171 & 59.14 & 235 & 11.87 & 574 & 28.99 & 1980 & 100 \\
\hline & Total & 3770 & - & 6915 & - & 9115 & - & 19800 & 100 \\
\hline & Average & 377 & 19.04 & 691.5 & 34.92 & 911.5 & 46.04 & 1980 & 100 \\
\hline
\end{tabular}


household facilities, has not been able to stem the sense of loss felt by the indigenous Old Finima population. Such dissatisfaction has been aggravated, recently by the non-direct payment of royalties from NLNG to New Finima Communities, as well as other unfulfilled mitigation promises and the plan to actualize the forced payment for electricity. However, study also revealed that, rather than taking advantage of the hitherto free electricity supply, many youths prefer to waste the energy on air-conditioner units, usually in dilapidated makeshift houses locally called "Basha houses".

Also, the interview sessions during the study revealed that the presence of NLNG, as well as other petroleum development multinational companies, including Mobil and S.P.D.C has resulted in unprecedented agitations, civil disobedience and community protests, communities land seizure, police and military incursions and interventions, environmental pollution (even NLNG releases unused gases from about three to four towering and noticeable columns and also generate solid wastes, in its liquefaction activities), and explosive increase in non-indigenous population .

Oral interviews and transect walks, during which observations were made in various sessions, further indicated that the NLNG residential area (RA) and other residential areas own by other multinationals are in contrast to the pathetic conditions under which the indigenous population of the host communities live, and from where the low income labor forces for the multinational companies come from. The presence, of such well-planned oil and gas companies Residential Areas (RA), with uninterrupted electricity and water supplies has created "Aesthetic Islands", which in the views of the indigenes are almost "Utopian Settlements" in the middle of "No Where".

Other negative implications observed and corroborated through focused group interviews include the emergence of high inflation level, increase in prostitution and prevalent use of alcohol, HIV/AIDS prevalence, induced and self-imposed distraction by women from matrimonial fidelity, as well as disregards for indigenous culture, norms and values, which were frequently mentioned by host community members. The existence of other energy resources exploiting multinationals and crude oil development company servicing firms has made associating, almost all of these negative outcomes, for instance prostitution and inflation, with one particular organization operating in the study area OUTRIGHTLY IMPOSSIBLE.

The elderly male respondents interviewed, also complained about neglect, since more confrontational youths, and especially younger women, have been major recipients of developmental benefits from Nigeria LNG Ltd. and other donors in the study area. In many communities studied by [7] and to a high extent in this study, male and female youths often advocate for higher education, employment and vocational training; married women for vocational training and a degree of financial independence, as well as hospitals/medical centres, especially maternity medical facilities. Elderly men have paradoxically usually requested for town halls. Perhaps out of concern for ceremonial activities hosting, such as weddings of their children, chieftaincy titles confirmation, burial ceremonies, grand receptions, society, club and political meetings. There however is high desire for increased post-retirement income and education of offsprings observed in this study.

\section{Conclusions}

Given that the NLNG project is the pioneer LNG project in the country, an in-depth understanding of its hindsight multi-dimensional impact, become rationally mandatory. Literature is saturated with pre-project (proactive) impact assessment reports on the NLNG project and sparsely on retrospective impact findings. The need to assess the retrospective benefits and demerits of the NLNG project, has suggested the execution of this study. This analytical effort is aimed at examining the socio-economic contributions of the natural gas liquefaction project on Bonny Island on its host communities, and others distant relevant communities, including those through which the feeder gas pipes traverse.

The study examined the Nigeria LNG Ltd.'s CDCSR activities up to the year 2010. This focused largely at the comparative provision of infrastructures and programmes, by Nigeria LNG Ltd. and other donors. The outcome of this study includes the identification of positive and negative impacts of the project in the study. The research also involved a comparative assessment of the level of satisfaction of the immediate host and distant communities, with NLNG's community development provisions, against the background of the level of performance of other donors, in the study area. The contribution to health management and administration of pharmaceutical preparation for deworming was also identified.

The study revealed that comparatively, NLNG project has made much more innovative positive socio-economic contributions to the study area, than the three tiers of government and other donors. Interviews of res- 
pondents indicated inadequacy of benefits from all the multinational donors, since there were multiple unfulfilled promises. However, Nigeria LNG Ltd. was ranked highest among the donors, based on its comparative performance, despite the desire of host communities for more accruing benefits.

Surprisingly, agitations against the CDCSR activities of Nigeria LNG Ltd. have not overshadowed its developmental provisions especially in the educational, health and physical development sectors. There are concerns about the close-door strategies of energy project proponents, including NLNG, SPDC and Mobil to information dissemination on its environmental management and compliance activities in the Bonny LGA, and especially the whole of the Niger Delta Area of Nigeria. Consequently, there is a dire need to review several aspects of Nigeria LNG Project Ltd.'s community development activities, especially in the area of more participatory project conception and community consultation, for better acceptance of programmes and projects by indigenous host communities. The participatory appraisal methods adopted revealed the need for improvement of benefits accruing to elderly persons in the host and pipeline communities.

\section{Recommendations}

In other to solve the various, developmental problems in the study area, the following recommendations are made:

1) Host community members should be increasingly involved in participatory infrastructural project selection and execution.

2) The employment of qualified indigenes should be encouraged to promote level of participation in decision making, within the Nigeria LNG Ltd's mechanism.

3) More productive dialogue and more effective conflict resolution systems should be evolved.

4) Nigeria LNG Ltd. should create adequate complaint communication and feedback channels with host communities.

5) There should be greater efforts to adhere to the Environmental Management Plan (EMP) which is a standalone document detached from the Environmental Impact Statement, and meant to mitigate impact in multidimensional ways.

\section{References}

[1] O’Rourke, D. and Connolly, S. (2003) Just oil? The Distribution of Environmental and Social Impacts of Oil Production and Consumption. Reviews in Advance, 28, 05.1-05.31.

http://www.moles.org/ProjectUnderground/oil/nigeria/burning.html

[2] Ashton, N.J., Arnott, S. and Douglas, O. (1999) The Human Ecosystems of the Niger Delta—An ERA Handbook. Environmental Rights Action, Lagos, 22.

[3] Ambio (1995) Perception and Reality: Assessing Priorities for Sustainable Development in the Niger River Delta. Ambio, 24, 527-538.

[4] Manby, B. (1999) The Price Of Oil: Corporate Responsibility and Human Rights Violations in Nigeria’s Oil Producing Communities. Human Rights Watch, New York, 202.

[5] Africa News Service (2003) Oil Companies and Gas Flaring in Niger Delta. October 14, 2003. Africa News Service, Lagos.

[6] McKay, J. (2006) Sakhalin-II Reaches Crossroads. LNG Journal, March 2006, Maritime Content Ltd., London.

[7] Akintoye, O.A (2002) Impact of Logging on Non-Logged Species and Effects on Socio-Economic Development in Ikom Local Government Area. A Master of Science Degree Thesis, Department of Geography and Regional Planning, University of Calabar, Calabar.

[8] Asiabaka, C.C., Agumagu, A.C., Ofor, M.C., Mac-Ogonor, C.U., Asiabaka, I.P., Akintoye, O.A., Wordu, S.A., Nwagwu, J.U., Eleonu, C. and Akari, E. (2001) Shell Petroleum Development Company Limited: Ubie Node Integrated Oil and Gas Project Social Impact Assessment Baseline Study Draft Report. Sustainable Environment and Socio-Economic Development group (SESDEG), Owerri.

[9] SPDC (2007) Environmental Impact Assessment (EIA) for Gbaran Field Logistics Base (FLB)/Jetty for Gbaran/Ubie Integrated Oil and Gas Project Final Report. Shell Petroleum Development Company of Nigeria Ltd. Operator for the NNPC/Shell/Agip/Total Venture, Port Harcourt.

[10] Lee, J.A. (1985) The Environment, Public Health and Human Ecology: Considerations for Economic Development. The John Hopskins University Press, London. 
[11] Kellman, M. and Tackaberry, R. (1997) Tropical Environments: The Functioning and Management of Tropical Ecosystems. Routledge, New York. http://dx.doi.org/10.4324/9780203392843

[12] Wikipedia (2016) Corporate Social Responsibility. https://en.wikipedia.org/wiki/Corporate_social_responsibility

[13] Joint Industries Companies (2002) Bonny Master Plan Tender Contract. E-10654 Draft Final Report, Existing Conditions, No. 114-RPT-PM REV. 1, Port Harcourt.

[14] Nigeria LNG Limited (2008) Environmental Impact Assessment (EIA) for the NLNGplus Project: Executive Summary. Nigeria Liquefied Natural Gas plus Ltd, Bonny.

[15] Nigeria LNG Limited (2003) HIV/AIDS Awareness Campaign Still on Course. Host Magazine, Third Quarter, 2003, A Nigeria LNG Community Magazine, Publication Unit, External Relations Division, Nigeria LNG Limited, Lagos.

[16] Nigeria LNG Limited (2005) Cash Anytime. The NLNG Bond Magazine, In-House Magazine of the Nigeria LNG Limited, Publication Unit, External Relations Division, Nigeria LNG Limited, Lagos.

[17] The LNG Limited (2008) A Kingdom: Bonny and Rare. Publication Unit, External Relations Division, Nigeria LNG Limited, Lagos.

[18] Nigeria LNG Limited (2009) Making of Ultra-Modern Bonny. Host Magazine Bumper Anniversary Edition, In-House Magazine of the Nigeria LNG Limited, Publication Unit, External Relations Division, Nigeria LNG Limited, Lagos.

[19] Nigeria LNG Limited (2009) LNG from Nigeria, NLNG; The Magazine, The In-House Magazine of the Nigeria LNG Limited, Publication Unit, External Relations Division, Nigeria LNG Limited, Lagos.

[20] Nigeria LNG Limited (2010) Facts and Figures on NLNG. Publication Unit, External Relations Division, Nigeria LNG Limited, Lagos.

[21] Nigeria LNG Limited (2010) Building Vocational Capacity in Nigeria. NLNG Corporate Social Responsibility Digest, A Publication of the External Relations Division on NLNG Corporate s, External Relations Division of Nigeria Liquefied Natural Gas Ltd., C and C Towers, Victoria Island Lagos.

[22] Hart, N. (2005) ECG Machine for Bonny General Hospital’ In Nigeria LNG Limited (2005) Staying Alive: NLNG Begins Deworming Exercise in Communities, Host Magazine, Second Quarter, 2005, A Community Magazine by the External Relations Division on NLNG's Corporate Social Responsibility.

[23] Hart, N. (2005) Staying Alive: NLNG Takes Battle Against Worm to Host and Pipeline Communities’ In Nigeria LNG Limited (2005) Staying Alive: NLNG Begins Deworming Exercise in Communities, Host Magazine, Second Quarter, 2005, A Community Magazine by the External Relations Division on NLNG's Corporate Social Responsibility, Lagos.

[24] Akintoye, O.A (2014) Socio-Economic and Health Consequences of the Nigeria Liquefied Natural Gas Project in Bonny Local Government Area, Rivers State. A Doctor of Philosophy PhD, Degree Dissertation, Department of Geography, University of Nigeria, Nsukka. 